DOI: $10.17805 /$ trudy.2019.4.8

\title{
ДИАГНОСТИКА ГОТОВНОСТИ К ИННОВАЦИОННОЙ ДЕЯТЕЛЬНОСТИ ПЕДАГОГОВ ШКОЛЫ (НА ПРИМЕРЕ ГБОУ ШКОЛА № 1637)
}

\author{
М. К. Иванова \\ Московский гуманитарный университет
}

\begin{abstract}
Аннотация: В статье рассматривается проблема готовности педагога кинновационной деятельности. Представлены компоненты и уровни готовности учителя к инновационной деятельности в условиях реализации федерального государственного образовательного стандарта основного общего образования.
\end{abstract}

Ключевые слова: инновационная деятельность; профессиональная компетентность; педагог; проблемы образования; ФГОС

\section{DIAGNOSTICS OF SCHOOL TEACHERS' READINESS FOR INNOVATIVE ACTIVITY (USING SCHOOL NO. 1637 AS AN EXAMPLE)}

\author{
M. K. Ivanova \\ Moscow University for the Humanities
}

Abstract: The article discusses the issue of readiness for innovative activity of a teacher. It presents the components and levels of teachers' preparedness for innovative activities against a background of implementing the federal state educational standard of general secondary education.

Keywords: innovative activity; professional competency; teacher; issues of education; FSES

В связи с переходом российского системы общего образования на систему государственных стандартов, требования к современным педагогам заметно повышаются. В ФГОС основного общего образования инновационное развитие современной школы названо приоритетным направлением и его реализация подразумевает готовность педагогов к инновациям.

Тема готовности педагога к инновационной деятельности нашла отражение в исследованиях Н. Ф. Ильиной, Б. И. Канаева, С. А. Квашниной, В. С. Лазарева, Р. А. Льговой, Л. С. Подымовой, В. А. Сластенина, В. З. Юсупова и др. В них готовность педагога к инновационной деятельности рассматривается как составная часть процесса становления профессиональной компетентности педагога. В. А. Сластенин и Л. С. Подымова указывают, что инновационная деятельность является социально-педагогическим феноменом, а также важнейшей особенностью педагогического труда, которая характе- 
Научные труды Московского гуманитарного университета 2019 № 4

ризует сложную сущностную взаимосвязь общей культуры педагога, его творческого потенциала и профессиональной направленности (Сластенин, Подымова, 2007).

Учитывая то, что инновационное развитие школы становится приоритетным направлением, необходимость проведения диагностики готовности педагогов к инновационной деятельности в школе становится очевидной.

Под готовностью к инновационной деятельности С. Б. Куликов понимает внутреннюю силу, которая формирует инновационную позицию педагога. Готовность к инновационной деятельности является предпосылкой эффективной деятельности педагога, максимальной реализации его возможностей, раскрытия творческого потенциала. (Куликов, 2005). В. 3. Юсупов предпосылкой формирования готовности к инновационной проектной деятельности считает освоение четырёх групп источников: «культурно-исторические источники, демонстрирующие опыт развития проективной способности человека в различных видах его продуктивного труда; социально-педагогические источники, которые составляют идеи, концепции, практический опыт решения проблем образования средствами проектной деятельности; теоретико-методологические источники, дающие представление об общих методологических основаниях, закономерностях, присущих инновационным проектам во всех областях деятельности; конвенциональные источники, представляющие собой совокупность правил, требований, норм разработки и реализации инноваций» (Юсупов, 2018: Электр. ресурс).

Мы понимаем под готовностью к инновациям индивидуальное проявление творческого стиля деятельности, в котором сочетаются определенная личностная направленность знания и практические умения реализовать новые способы и формы осуществления профессиональной деятельности.

Т. И. Сергеева и С. В. Панина, проведя анализ педагогической теории и практики, выделили основные компоненты и уровни готовности педагога к инновационной деятельности. Так, высокий уровень отражает полную готовность учителя к инновационной деятельности. Его составляющими выступают: 1) мотивационный компонент - принятие инноваций как личностной ценности; мотив как способ реализации творческого потенциала; готовность к непрерывному образованию; 2) когнитивный компонент - знание инновационных технологий обучения; владение способами проектирования новых образовательных результатов. 3) деятельностный компонент - внедрение инновационных технологий: разрабатывать и реализовывать проекты, вести исследовательскую деятельность и др.). Что касается готовности низкого уровня, то она может быть сформирована в результате длительного саморазвития, принятия идей федеральных стандартов (Сергеева, Панина, 2017). 
По мнению Е. Э. Воропаевой, комплекс мер по развитию возможностей педагога к участию в инновационной деятельности образовательной организации включает: 1) диагностику уровня инновационного потенциала; 2) создание инновационного информационного образовательного фонда; 3) сотрудничество с научными учреждениями; 4) выбор педагогами новшеств в соответствии с учетом интересов учащихся, связанных с тематикой опытно-экспериментальной работы школьного коллектива, запросами родителей, потребностями школы; 5) совершенствование структуры управления в условиях работы в инновационном режиме, активное участие педагогов в принятии управленческих решений; 6) Мотивация педагогов на достижение успеха (Воропаева, 2014: Электр. ресурс).

Н. Ф. Ильина полагает, что система показателей готовности и возможности участия педагога в инновационной деятельности включает: личное отношение к внедряемым в школе инновациям, собственная роль в их развитии, восприимчивость к новшествам, информационную и мотивационную готовность к освоению инноваций. Ильина Н.Ф. говорит о необходимости проведения опроса педагогов инициативной творческой группы, состоящей из представителей учителей, администрации, методических объединений (Ильина, 2014).

Основываясь на вышесказанном, можно сделать вывод, что готовность педагогов к инновационной деятельности и участие в ней считаются как напрямую зависящие от мотивации педагогов, а именно от личного отношения педагогов и готовности к вводимым новшествам, а также от творческих способностей, осознания себя, как части механизма, работающего на достижение поставленной цели, принятие этой цели как личной.

Исходя из приведённого анализа научной литературы, а также ввиду необходимости принятия мер для инновационного развития школы, нами была проведена диагностика готовности педагогического коллектива ГБОУ Школа № 1637 г. Москва к инновационной деятельности. Целью данной диагностики было определить степень осведомлённости педагогов о новшествах, реализуемых в образовательной организации, а также отношение к реализуемым проектам.

Анализ результатов данной диагностики показал, что высокий уровень степени осведомлённости педагогов о новшествах, реализуемых в данной образовательной организации показали 63\% педагогов; допустимый уровень степени осведомлённости педагогов о новшествах показали $35 \%$ педагогов; низкий уровень степени осведомленности педагогов о новшествах показали $2 \%$ педагогов; критический уровень степени осведомлённости педагогов о новшествах не обнаружен (диаграмма № 1). 


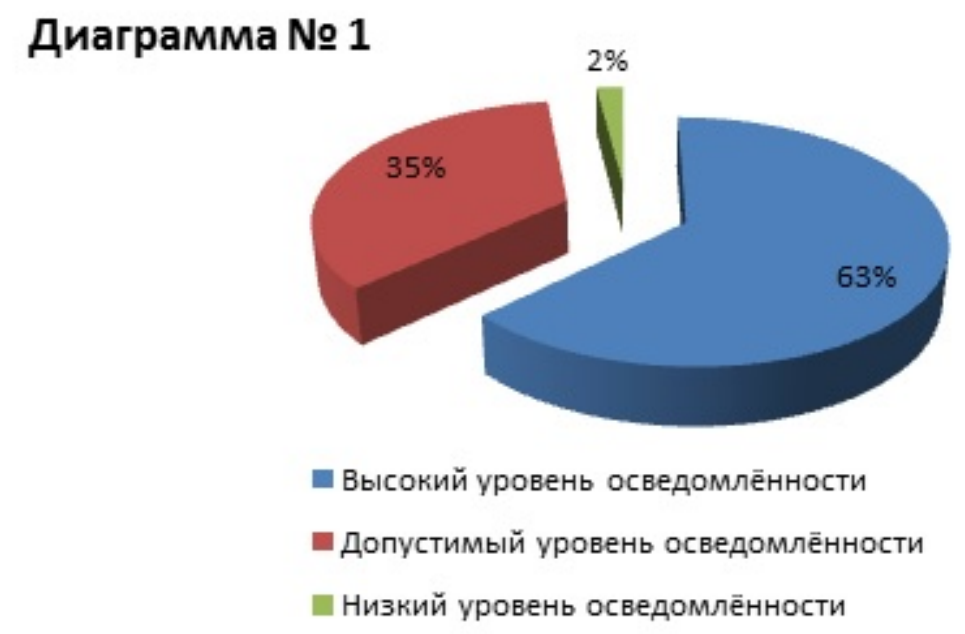

Положительное отношение к большинству реализуемых в школе проектам у $80 \%$ педагогов, нейтральное отношение наблюдалось у $20 \%$ педагогов, отрицательное отношение к большинству реализуемых проектов не наблюдалось (диаграмма № 2).

\section{Диаграмма №2}

п Положительное отношение п Нейтральное отношение

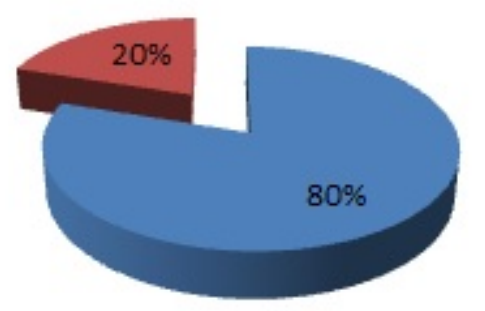

Также была проведена диагностика педагогического коллектива с целью определить степень готовности педагогического состава к инновационной деятельности. Из результатов диагностики следует, что готовность на высоком уровне показали $37,5 \%$ педагогов, принимавших участие в ис-

\section{Диаграмма №3}

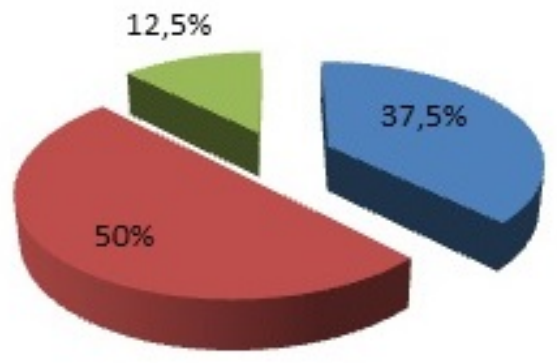

- Высокий уровень

- Средний уровень

Шизкий уровень 
следовании. У 50\% педагогического состава уровень готовности к инновационной деятельности средний. $12,5 \%$ педагогов имеют низкую готовность к инновациям (диаграмма № 3).

Анализ диагностики проводился по четырём критериям, а именно отслеживалась мотивационно-творческая направленность педагогического коллектива, креативность, самооценка профильных возможностей и индивидуальных особенностей педагогов. В результате диагностики по данным критериям 50\% педагогического коллектива стремятся к самосовершенствованию, к творческим достижениям, к лидерству. 50\% педагогов заинтересованы в творческой деятельности, но слабо заинтересованы в самосовершенствование. Педагогов не заинтересованных в творческой деятельности, не стремящихся к творческим достижениям, для которых лидерство и самосовершенствование не является приоритетным среди педагогического коллектива ГБОУ Школа № 1637 не выявлено (диаграмма № 4).

\section{Диаграмма № 4}
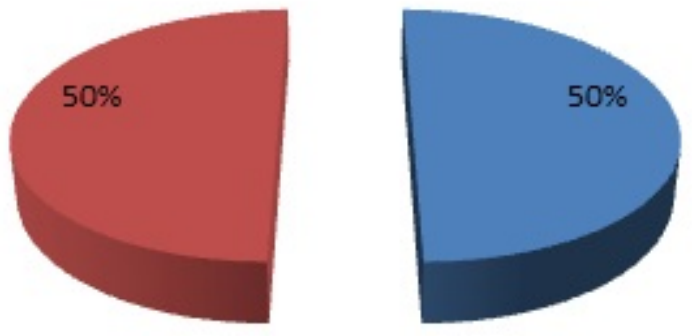

- Высокий уровень

п Средний уровень

Креативность 50\% педагогов находится на среднем уровне. 37,5\% педагогического коллектива оцениваю себя, как высоко креативную личностью, 12,5\% педагогического коллектива считают себя некреативными личностями (диаграмма № 5).

\section{Диаграмма № 5}

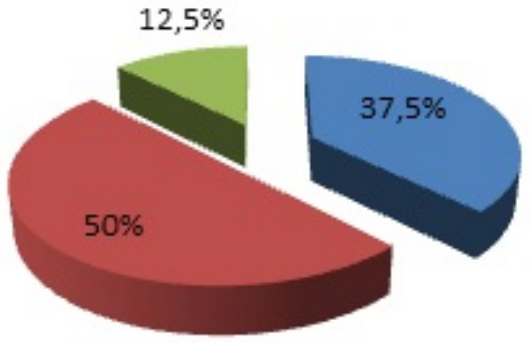

— Высокий уровень

- Средний уровень

ш Низкий уровень 
По критерию самооценка профессиональных способностей к инновационной деятельности 37,5\% педагогического коллектива владеют методами педагогического исследования, способны планировать экспериментальную работу и организовывать эксперимент. 62,5\% педагогов отмечают недостаточное овладение методами педагогического исследования, но способны к сотрудничеству и использованию опыта творческой деятельности других педагогов (диаграмма № 6, 0\% обычно в диаграммах не отражается).

\section{Диаграмма № 6}

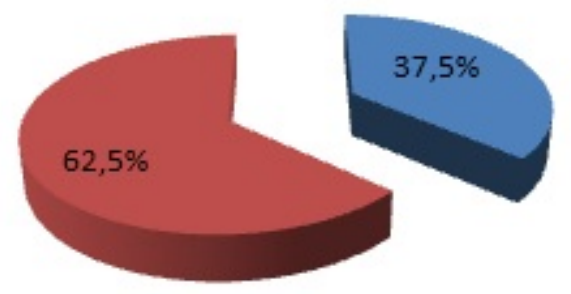

— Высокий уровень

п Средний уровень

Что касается индивидуальных особенностей личности педагогов, то 25\% педагогов оценивают себя как ответственных, уверенных в себе личностей, с высокой работоспособностью в творческой деятельности. 67,5\% отмечают недостаточную уверенность в себе и недостаточную работоспособность в творческой деятельности. 12,5\% не уверены в социальной значимости творческой деятельности, способность к самоорганизации слабо развита, работоспособность в творческой деятельности низкая (диаграмма № 7).

\section{Диаграмма № 7}

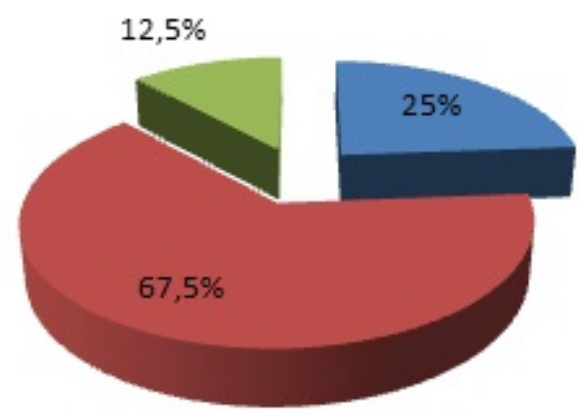

$$
\begin{aligned}
& \text { Высокий уровень } \\
& \text { — Средний уровень } \\
& \text { Шизкий уровень }
\end{aligned}
$$

Основываясь на анализе результатов проведённой диагностики, можно сделать вывод, что педагогический коллектив ГБОУ Школа № 1637 хорошо осведомлён о инновациях, вводимых образовательной организацией и имеет положительное отношение к ним, однако готовность участвовать 
в инновационной деятельности находится на среднем уровне. Это может быть обусловлено низкой самооценкой профессиональных способностей педагогов к инновационной деятельности, которая выражается в недостаточной уверенности в себе, работоспособности в творческой деятельности, а также неумением планировать экспериментальную работу.

\section{СПИСОК ЛИТЕРАТУРЫ}

Воропаева, Е. Э. (2014) Структура и критерии готовности педагога к инновационной деятельности [Электронный ресурс] // Современные проблемы науки и образования. № 4. URL: http://www.science-education.ru/ru/ article/view?id=13880 (дата обращения: 07.05.2019).

Ильина, Н. Ф. (2014) Становление инновационной компетентности педагога в региональном пространстве непрерывного образования : автореф. дис. ... д-ра пед. наук. Красноярск. 42 с.

Куликов, С. Б. (2005) Инновационная направленность современного образования как проблема философии науки // Сибирский педагогический журнал. № 1. С. 62-69.

Сластенин, В. А., Подымова, Л. С. (2007) Готовность педагога к инновационной деятельности // Сибирский педагогический журнал. № 1. С. 42-49.

Сергеева, Т. И., Панина, С. В. (2017) Готовность учителя к инновационной деятельности в условиях реализации ФГОС // Общество: социология, психология, педагогика. № 1. С. 117-119.

Юсупов, В. 3. (2018) Источники, методологические основы и понятийный аппарат проектного управления в педагогическом менеджменте [Электронный ресурс] // Научные труды Московского гуманитарного университета. № 4. URL: http://journals.mosgu.ru/trudy/article/view/806 (дата обращения: 10.08.2019). DOI: 10.17805/trudy.2018.4.2

Дата поступления: 15.08.2019 г.

Иванова Мария Константиновна - магистрант кафедры педагогики и психологии высшей школы Московского гуманитарного университета. Адрес: 111395, Россия, г. Москва, ул. Юности, д. 5. Тел.: + 7 (499) 374-74-59. Эл. адрес: Ivanovamasha1993@yandex.ru. Научный руководитель - д. п. н., проф. В. З. Юсупов.

Ivanova Maria Konstantinovna, Graduate Student, Department of Pedagogy and Psychology of Higher Education, Moscow University for the Humanities. Postal address: 5, Yunosti St., Moscow, Russian Federation, 111395. Tel.: +7 (499) 37474-59. E-mail: Ivanovamasha1993@yandex.ru. Scientific Adviser - V. Z. Yusupov, Doctor of Pedagogy, Professor. 


\section{Для цитирования:}

Иванова М. К. Диагностика готовности к инновационной деятельности педагогов школы (на примере ГБОУ школа № 1637) [Электронный ресурс] // Научные труды Московского гуманитарного университета. 2019. № 4. URL: http://journals.mosgu.ru/trudy/ article/view/1016 (дата обращения: дд.мм.гг.). DOI: 10.17805/trudy.2019.4.8 